\title{
The effect of biodegradable direct covers on the root development, yield and quality of cucumber
}

\author{
Izabela Zawiska*, Piotr Siwek \\ Department of Vegetable and Medicinal Plants \\ University of Agriculture in Krakow \\ 29 Listopada 54, 31-425 Kraków, Poland
}

\begin{abstract}
The results of three years (2009-2011) of field studies using two types of biodegradable nonwoven covers (aromatic polyester IBWCH $75 \mathrm{~g} \mathrm{~m}^{-2}$ and polylactic acid PLA $54 \mathrm{~g} \mathrm{~m}^{-2}$ ) on the yield, quality and root development of cucumber are presented. Seeds of parthenocarpic cucumber ('Mirabelle' $F_{1}$ ) were sown directly into the field at the beginning of May/June and covered with nonwoven field covers. A plot that remained uncovered served as the control. The covers were kept in place until the first flowers appeared. Cucumbers were harvested every three days for 5-6 weeks. Fruits were evaluated for dry matter, soluble sugars and nitrate content. After the last harvest, whole plants were harvested and evaluated for weight, surface area, total length and average diameter of the roots. The experiment showed that the covers increased the marketable yield of cucumber in 2009 and 2010 (regardless of the type of polymer), but did not influence the yield in 2011. In 2011 the fruits from the covered plots had higher levels of soluble sugars and dry matter in comparison to the control. The covers did not influence root development.
\end{abstract}

Key words: crop covers, field cultivation, yielding

\section{INTRODUCTION}

Field production, especially early and late in the six-month season of cucumber in temperate climate zones, is constrained by low temperatures. Cucumbers are a valuable crop but growth and early yields are limited by cold conditions in spring and fall. They are usually transplanted to the field by the second half of May, therefore there is high interest among vegetable growers in systems to extend the harvest season (Adams et al. 2001). Methods that would enable earlier transplanting into the field such as covering may hasten the growth and development of plants through temperature moderation and protection from light frosts. In the presented experiment the covers were placed directly onto top of the plants without any wire hoops. This technique is a common method of covering plants in Poland which has the potential to create a warm, calm microclimate favourable to plant development - especially warm season crops, such as cucumber, growing in cool environment. The main aim of covering is to improve microclimate conditions in the immediate surroundings of the plants, especially air temperature and humidity (Otto et al. 2000); it may also reduce insect damage (Lamont 1993). Other attributed advantages of direct cover are improvements in plant uniformity and fruit quality, as well as yield increases and the extension of the harvesting season.

\footnotetext{
*Corresponding author.

Tel.: +48 1266252 17; fax: +48 124111300 ;

e-mail: iza.zawiska@interia.pl (I. Zawiska).
} 
In the available literature there are many studies that illustrate the beneficial effects of crop covering upon the yield and quality of vegetables. Covers commonly used by vegetable growers are usually made of flexible transparent to semi-transparent synthetic materials (mainly polyethylene and polypropylene) and are used to cover one or more rows of plants (Hochmuth et al. 2003). The popularity of synthetic covers can be attributed to their low cost, ease of application and durability. One limitation of crop covers is the problem of their disposal once they are no longer needed in the field. These materials cannot degrade in the environment through microorganisms (Siwek et al. 2012). Although the influence of direct covering on the earliness and productivity of various vegetable crops like tomato, cucumber (Wolfe et al. 1989), onion (Orłowski et al. 2005), lettuce (Rekowska 2011) or zucchini (Adamczewska-Sowińska and Kołota 2011) has been studied, scientific information on the use of biodegradable nonwoven covers is scarce.

The present study examines the effect of covering cucumbers with biodegradable nonwoven crop covers on marketable fruit yield and fruits quality. An additional aspect of the work concerned investigations of direct covering on root development and some parameters of root growth. As the authors did not find any articles on this subject, it seemed important and interesting to evaluate how and if biodegradable direct covers influence the roots.

\section{MATERIAL AND METHODS}

The study was carried out in 2009-2011 at the Experimental Station of the University of Agriculture in Kraków. 'Mirabelle' $\mathrm{F}_{1}$ cucumber (Cucumis sativus L.) was grown under two types of crop covers made of biodegradable nonwoven (melt - blown type) that were produced in the Institute of Biopolymers and Chemical Fibres and CENARO in Łódź (Poland). The covers were manufactured from aromatic polyester (IBWCH $75 \mathrm{~g} \mathrm{~m}^{-2}$ ) and polylactic acid (PLA $54 \mathrm{~g} \mathrm{~m}^{-2}$ ). A plot that remained uncovered served as the control. Each year new covers were used.

Cucumber seeds were sown into the field on 15.05, 10.06 and 17.05 in 2009, 2010 and 2011, respectively, in spacing of $25 \times 200 \mathrm{~cm}$ and immediately after seeding each row was covered with biodegradable nonwovens that were kept until 17.06, 29.06 and 23.06 in 2009, 2010 and 2011. The time for removing covers was suitably chosen based on plant development, growing temperatures and humidity under covers. Low temperatures and high rainfalls delayed seeding in 2010.

The field was fertilised with ammonium nitrate before seed sowing, based on soil test recommendations $(70 \mathrm{~kg} \mathrm{~N}$ per ha in 2009 , $80 \mathrm{~kg} \mathrm{~N}$ per ha in 2010 and $80 \mathrm{~kg} \mathrm{~N}$ per ha in 2011). Each experimental plot was $7.5 \mathrm{~m}^{2}$ (15 plants each) randomly arranged in blocks with four replications. Fruit were collected every three days, from 09.07 till 17.08 in 2009 , from 21.07 till 31.08 in 2010 and from 12.07 till 26.08 in 2011. The marketable yield was determined according to Polish Norm (PN-85/R-75359). In the middle of the harvest season 50 fruits from each combination were collected for quality analyses. Furthermore, fruit were evaluated for dry weight (using the drying method at $70^{\circ} \mathrm{C}$ ), soluble sugars (using the anthrone method (Yemm and Willis 1954)) and nitrate content (with the use of ion-selective electrodes). In 2010 and 2011 at the last harvest, all plants were excavated from the soil to estimate root growth and development with the use of the RadixNova computer programme (Bauhus and Messier 1999, Kimura et al. 1999). This analysis generated estimates of weight, surface area, total length and average diameter of roots grown in three different configurations (two different biodegradable crop covers and one without cover).

The covers were analysed for their spectral transmission, reflection and absorption of radiation within the range of 400-1100 nm, using LI-180012-S (LI-COR, USA) integration sphere with a standard light source. All data were subjected to an analysis of variance using the Statistica program. Tukey's HSD test was used to estimate the significance of differences at $\mathrm{p}=0.05$.

\section{RESULTS AND DISCUSSION}

The modification of conditions using crop covering largely depends on the optical parameters of the cover materials. In this study the transmittance and absorbance was higher for the PLA $54 \mathrm{~g} \mathrm{~m}^{-2}$ cover, whereas the reflectance of radiation was higher for the IBWCH $75 \mathrm{~g} \mathrm{~m}^{-2}$ cover (Tab. 1). Siwek (2002) used films with similar optical parameters in an experiment that involved covering cucumber with polyethylene and polypropylene covers. The reflectance of biodegradable nonwovens applied in this experiment was $80 \%$ higher than the reflectance of the polypropylene nonwoven PP $20 \mathrm{~g}$ $\mathrm{m}^{-2}(17.4 \%)$ used by Siwek (2002) within the same range of radiation. 
Table 1. Transmittance, absorbance and reflectance $(\%)$ of new nonwoven biodegradable crop covers in the range 400-700 nm (PAR) and 700-1100 nm

\begin{tabular}{lccc}
\hline Cover & Transmittance & Absorbance & Reflectance \\
\hline PLA $\left(54 \mathrm{~g} \mathrm{~m}^{-2}\right)$ & 65.8 & 9.1 & 25.1 \\
IBWCH $\left(75 \mathrm{~g} \mathrm{~m}^{-2}\right)$ & 59.7 & 2.8 & 37.5 \\
\hline
\end{tabular}

The improvement of the microclimate in the immediate environs of vegetable plants covered with biodegradable nonwovens in spring was a factor that caused faster growth and led to a higher yields than in cultivation without covers. The effect was especially seen in the first two years of the experiment (2009 and 2010). The marketable yield of cucumber was higher when biodegradable covers were used relative to the yield obtained from the non-covered control (Tab. 3). The beneficial effect of the cover was similar for both biodegradable nonwovens. Low temperatures and heavy rainfalls that occurred in 2010 and 2011 might have caused the yield decrease when compared with the yield obtained in 2009 (Tab. 2).

The positive effects of using polypropylene (PP) and polyethylene (PE) row covers have been previous noted. Siwek (2002) showed that the marketable fruit yield obtained from cucumbers grown under covers (both PP and PE) was significantly higher than the yield from plants grown in a control treatment (without covers). Orłowski et al. (2005) observed that covering onions with polyethylene covers increased yields by $12 \%$ in comparison to the control. Rekowska (2011) showed that the yield of lettuce from covered treatments was higher than from treatment where covers were not used.

Table 2. Air temperature and rainfall during field cultivation of 'Mirabelle' $\mathrm{F}_{1}$ cucumber under biodegradable nonwovens in the years 2009-2011

\begin{tabular}{|c|c|c|c|c|c|c|c|}
\hline \multirow{2}{*}{ Month } & \multirow{2}{*}{ Ten days } & \multicolumn{3}{|c|}{ Air temperature $\left({ }^{\circ} \mathrm{C}\right)$} & \multicolumn{3}{|c|}{ Rainfall (mm) } \\
\hline & & 2009 & 2010 & 2011 & 2009 & 2010 & 2011 \\
\hline \multirow{4}{*}{ April } & I & 13.0 & 6.6 & 10.3 & 0.1 & 10.0 & 0.1 \\
\hline & II & 11.4 & 8.4 & 8.4 & 0.0 & 26.1 & 0.4 \\
\hline & III & 11.8 & 10.5 & 13.6 & 0.4 & 1.2 & 0.2 \\
\hline & Mean/sum per month & 12.0 & 8.5 & 10.7 & 0.5 & 37.3 & 0.7 \\
\hline \multirow{4}{*}{ May } & I & 13.0 & 12.7 & 9.6 & 10.2 & 74.9 & 16.0 \\
\hline & II & 13.1 & 10.9 & 15.4 & 24.2 & 188.0 & 1.2 \\
\hline & III & 13.8 & 14.5 & 17.2 & 56.6 & 35.0 & 24.6 \\
\hline & Mean/sum per month & 13.3 & 12.7 & 14.1 & 91.0 & 297.9 & 41.8 \\
\hline \multirow{4}{*}{ June } & I & 13.6 & 18.0 & 19.4 & 21.1 & 71.0 & 26.0 \\
\hline & II & 15.0 & 18.0 & 18.4 & 35.5 & 29.4 & 3.6 \\
\hline & III & 17.8 & 16.9 & 17.9 & 71.4 & 21.6 & 11.4 \\
\hline & Mean/sum per month & 15.4 & 17.6 & 18.5 & 128.0 & 122.0 & 41.0 \\
\hline \multirow{4}{*}{ July } & I & 19.4 & 19.8 & 17.3 & 28.3 & 6.6 & 45.0 \\
\hline & II & 19.3 & 26.3 & 20.1 & 21.4 & 31.6 & 62.2 \\
\hline & III & 19.7 & 19.3 & 16.5 & 33.0 & 72.2 & 55.8 \\
\hline & Mean/sum per month & 19.4 & 21.8 & 17.9 & 82.7 & 110.4 & 163.0 \\
\hline \multirow{4}{*}{ August } & I & 19.8 & 19.9 & 18.7 & 1.4 & 27.8 & 23.0 \\
\hline & II & 18.1 & 19.6 & 19.2 & 12.7 & 38.0 & 5.8 \\
\hline & III & 18.8 & 16.9 & 20.3 & 39.0 & 72.4 & 8.4 \\
\hline & Mean/sum per month & 18.9 & 18.8 & 19.4 & 53.1 & 138.2 & 37.2 \\
\hline \multirow{4}{*}{ September } & I & 16.3 & 11.7 & 16.5 & 12.8 & 53.2 & 8.4 \\
\hline & II & 15.2 & 13.4 & 15.8 & 17.1 & 9.8 & 8.6 \\
\hline & III & 13.8 & 12.1 & 14.2 & 4.9 & 29.4 & 1.4 \\
\hline & Mean/sum per month & 15.1 & 12.4 & 15.5 & 34.8 & 92.4 & 18.4 \\
\hline
\end{tabular}


Table 3. Effect of biodegradable nonwoven used as row covers on the cumulative marketable yield of 'Mirabelle' $F_{1}$ cucumber $\left(\mathrm{kg} \mathrm{m}^{-2}\right)$

\begin{tabular}{lllll}
\hline Cover & 2009 & 2010 & 2011 & Mean \\
\hline PLA $\left(54 \mathrm{~g} \mathrm{~m}^{-2}\right)$ & $4.20 \mathrm{~b}^{*}$ & $2.16 \mathrm{~b}$ & $0.54 \mathrm{a}$ & $3.52 \mathrm{~B}$ \\
IBWCH $\left(75 \mathrm{~g} \mathrm{~m}^{-2}\right)$ & $4.14 \mathrm{~b}$ & $1.47 \mathrm{ab}$ & $1.00 \mathrm{a}$ & $1.55 \mathrm{~A}$ \\
Control (without cover) & $2.23 \mathrm{a}$ & $1.02 \mathrm{a}$ & $0.70 \mathrm{a}$ & $0.74 \mathrm{~A}$ \\
\hline
\end{tabular}

"Values marked with the same lowercase and uppercase letters do not differ significantly at $\mathrm{p}=0.05$

The presented experiment concerned the use of biodegradable materials as row covers, which is not a common practice at present. Siwek et al. (2012) used two types of biodegradable (BIONOLLE 100 $\mathrm{g} \mathrm{m}^{-2}$ and IBWCH $75 \mathrm{~g} \mathrm{~m}^{-2}$ ) and one polypropylene (PP $50 \mathrm{~g} \mathrm{~m}^{-2}$ ) cover to cover lettuce. In the first year of the experiment the polypropylene cover as well as the other biodegradable nonwoven covers increased lettuce yield. In the second year none of the covers had any effect. Similar results were obtained in field studies with leek (Siwek et al. 2009), where total marketable yield from plants grown under biodegradable covers was significantly higher (by $30 \%$ ) than the yield obtained from the control.

Plants grown with abundant light usually contain more sugars (Nevins 1995). Conversely, it might be expected that plants grown under covers, even for a short period of time at the beginning of cultivation should have reduced sugar content, as the covers do reflect and absorb a portion of incoming light. In the first two years of this experiment cucumber fruit grown under covers had the same sugar concentration as fruit from plants in the control treatment (Tab. 4). This observation confirms that covers used in this experiment characterised with high light permeability and the time when covers were taken off was suitably chosen. In 2011 cucumbers harvested from plants that had been covered had more soluble sugars when compared with the control. Similar results were obtained by Rekowska (2011), who observed $2.49 \%$ more sugar in lettuce cultivated under polypropylene covers.

As sugars are both important compounds of dry matter and also provide energy, their impact on growth and sugar content are often similar. Siwek (2002) demonstrated that using polypropylene covers over cucumber did not cause significant differences in the dry matter content of the fruit. Błażewicz-Woźniak (2010) obtained the same results in studies with fennel cultivation. In the present studies the dry matter content differed amongst the years of the experiment. In 2009 the highest fruit dry matter content was found in cucumbers grown without cover, whereas in 2011 in cucumbers harvested from plots where biodegradable covers were used.

The nonwovens used influenced the nitrate content of the fruit. Regardless of the polymer the cover was made from, using covers decreased the nitrate content of the cucumber fruit when compared with control treatments, especially in 2009 and 2011. Irrespective of the terms the nitrate

Table 4. The effect of kind of biodegradable nonwoven covers used on dry matter, soluble sugar and nitrate content in 'Mirabelle' $F_{1}$ cucumber fruit

\begin{tabular}{|c|c|c|c|c|}
\hline \multirow[t]{2}{*}{ Cover } & 2009 & 2010 & 2011 & Mean \\
\hline & \multicolumn{4}{|c|}{ Dry matter $(\%)$} \\
\hline $\operatorname{PLA}\left(54 \mathrm{~g} \mathrm{~m}^{-2}\right)$ & $4.32 \mathrm{~b}^{*}$ & $4.22 \mathrm{ab}$ & $4.22 \mathrm{~b}$ & $4.25 \mathrm{~A}$ \\
\hline IBWCH (75 $\left.\mathrm{g} \mathrm{m}^{-2}\right)$ & $4.22 \mathrm{a}$ & $4.34 \mathrm{~b}$ & $4.21 \mathrm{~b}$ & $4.25 \mathrm{~A}$ \\
\hline \multirow[t]{2}{*}{ Control (without cover) } & $4.43 \mathrm{c}$ & $4.16 \mathrm{a}$ & $4.13 \mathrm{a}$ & $4.24 \mathrm{~A}$ \\
\hline & \multicolumn{4}{|c|}{ Soluble sugars $(\%)$} \\
\hline $\operatorname{PLA}\left(54 \mathrm{~g} \mathrm{~m}^{-2}\right)$ & $1.60 \mathrm{a}$ & $1.58 \mathrm{a}$ & $1.72 \mathrm{~b}$ & $1.63 \mathrm{~A}$ \\
\hline IBWCH (75 $\left.\mathrm{g} \mathrm{m}^{-2}\right)$ & $1.58 \mathrm{a}$ & $1.66 \mathrm{a}$ & $1.73 \mathrm{~b}$ & $1.65 \mathrm{~A}$ \\
\hline \multirow[t]{2}{*}{ Control (without cover) } & $1.66 \mathrm{a}$ & $1.66 \mathrm{a}$ & $1.68 \mathrm{a}$ & $1.64 \mathrm{~A}$ \\
\hline & \multicolumn{4}{|c|}{ Nitrates $\mathrm{NO}_{3}^{-}\left(\mathrm{mg} \mathrm{kg}^{-1}\right.$ f.w.) } \\
\hline $\operatorname{PLA}\left(54 \mathrm{~g} \mathrm{~m}^{-2}\right)$ & $213.11 \mathrm{~b}$ & $253.36 \mathrm{a}$ & $278.97 \mathrm{~b}$ & $248.48 \mathrm{~B}$ \\
\hline IBWCH (75 $\left.\mathrm{g} \mathrm{m}^{-2}\right)$ & $167.15 \mathrm{a}$ & $269.29 \mathrm{ab}$ & $249.90 \mathrm{a}$ & $228.78 \mathrm{~A}$ \\
\hline Control (without cover) & $239.73 \mathrm{c}$ & $290.37 \mathrm{~b}$ & $290.39 \mathrm{c}$ & $273.49 \mathrm{C}$ \\
\hline
\end{tabular}

*Explanations: see Table 3 
Table 5. Effect of biodegradable nonwoven row covers on weight, surface area, volume, total length and average diameter of 'Mirabelle' $F_{1}$ cucumber root system

\begin{tabular}{|c|c|c|c|}
\hline \multirow[t]{2}{*}{ Cover } & 2009 & 2010 & Mean \\
\hline & \multicolumn{3}{|c|}{ Root weight (g f.w. per plant) } \\
\hline $\operatorname{PLA}\left(54 \mathrm{~g} \mathrm{~m}^{-2}\right)$ & $9 a^{*}$ & $14 \mathrm{a}$ & $11 \mathrm{~A}$ \\
\hline IBWCH $\left(75 \mathrm{~g} \mathrm{~m}^{-2}\right)$ & $10 \mathrm{a}$ & $13 \mathrm{a}$ & $11 \mathrm{~A}$ \\
\hline \multirow[t]{2}{*}{ Control (without cover) } & $11 \mathrm{a}$ & $12 \mathrm{a}$ & $11 \mathrm{~A}$ \\
\hline & \multicolumn{3}{|c|}{ Root surface area ( $\mathrm{cm}^{-3}$ per plant) } \\
\hline $\operatorname{PLA}\left(54 \mathrm{~g} \mathrm{~m}^{-2}\right)$ & $425 \mathrm{a}$ & $360 \mathrm{a}$ & $392 \mathrm{~A}$ \\
\hline IBWCH $\left(75 \mathrm{~g} \mathrm{~m}^{-2}\right)$ & 463 a & $449 \mathrm{a}$ & $456 \mathrm{~A}$ \\
\hline \multirow[t]{2}{*}{ Control (without cover) } & $390 \mathrm{a}$ & $465 \mathrm{a}$ & $427 \mathrm{~A}$ \\
\hline & \multicolumn{3}{|c|}{ Root length (m per plant) } \\
\hline $\operatorname{PLA}\left(54 \mathrm{~g} \mathrm{~m}^{-2}\right)$ & $5.18 \mathrm{a}$ & $3.48 \mathrm{a}$ & $4.33 \mathrm{~B}$ \\
\hline IBWCH $\left(75 \mathrm{~g} \mathrm{~m}^{-2}\right)$ & $5.38 \mathrm{a}$ & $3.21 \mathrm{a}$ & $4.29 \mathrm{AB}$ \\
\hline \multirow[t]{2}{*}{ Control (without cover) } & $3.97 \mathrm{a}$ & $3.43 \mathrm{a}$ & $3.70 \mathrm{~A}$ \\
\hline & \multicolumn{3}{|c|}{ Average root diameter (mm per plant) } \\
\hline $\operatorname{PLA}\left(54 \mathrm{~g} \mathrm{~m}^{-2}\right)$ & $2.6 \mathrm{a}$ & $1.4 \mathrm{a}$ & $2.0 \mathrm{~A}$ \\
\hline IBWCH (75 $\left.\mathrm{g} \mathrm{m}^{-2}\right)$ & $2.7 \mathrm{a}$ & $1.4 \mathrm{a}$ & $2.1 \mathrm{~A}$ \\
\hline Control (without cover) & $2.4 \mathrm{a}$ & $1.5 \mathrm{a}$ & $2.0 \mathrm{~A}$ \\
\hline
\end{tabular}

*Explanations: see Table 3

content did not exceed the level of $400 \mathrm{NO}_{3}{ }^{-}$per $\mathrm{kg}$ of fresh weight limit determined by the European Union Commission Regulation (EC) No 1881/2006 for cucumber.

Little research has been conducted to examine root grow th and the development of plants cultivated with row covers. Most of this research focuses on the distribution of roots in the soil and root reaction to various stresses (Dalton et al. 1997, Sonneveld and Kreij 1999). In this study, covering cucumbers with biodegradable nonwovens at the start of the growing season had no impact on any of the root growth parameter examined (Tab. 5).

\section{CONCLUSION}

1. A positive effect of biodegradable nonwovens used as row covers on the cucumber fruit yield was demonstrated only when growing conditions were favourable, whereas due to unfavourable weather conditions no differences were observed.

2. Biodegradable nonwovens (regardless of the type of polymer) increased the yield in comparison to the control on average by $86 \%$ with the exception of 2011.

3. Using row covers did not influence the soluble sugar content in cucumbers in the first two years of the experiment, whereas the accumulation of nitrates was significantly lower in plants grown under biodegradable covers in the first weeks of cultivation.

4. No significant effect of using biodegradable nonwoven materials on root parameters was shown in the presented experiment.

\section{ACKNOWLEDGEMENTS}

The research was supported by a project grant from the Polish Ministry of Science and Higher Education - PBZ-MNiSW - 01/II/2007.

\section{REFERENCES}

AdamczewsKa-SowiŃsKa K., KoŁota E., 2010. Yielding and nutritive value of field cultivated eggplant with the use of living and synthetic mulches. Acta Sci. Pol., Hortorum Cultus 9(3): 191-199.

Adams S.R., Cockshul K.E., Cave C.J.R., 2001. Effect of temperature on the growth and development of tomato fruits. Ann. Bot. 88: 869-877.

Bauhus J., Messier CH., 1999. Evaluation of fine root length and diameter measurements obtained using RHIZO image analysis. Agron. J. 91: 142-147.

BŁAżEWICZ-WoźniaK M., 2010. Effect of soil land plant covering as well as sewing term upon fennel bulb nutritional value. Acta Sci. Pol., Hortorum Cultus 9(1): 3-12.

Commission Regulation (EC) No 1881/2006 of 19 December 2006 setting maximum levels for certain contaminants in foodstuffs.

Dalton F.N., Maggio A., Piccinni G., 1997. Effect of root temperature on plant response functions for 
tomato: comparison of static and dynamic salinity stress indices. Plant Soil 192: 307-319.

Hochmuth G.J., Hochmuth R.C., Kostewicz S., Stall W., 2003. Row covers for commercial vegetable culture in Florida. Florida Cooperative Extension Service, University of Florida, Circular 728.

Kimura K., Kikuchi S., Yamasaki S., 1999. Accurate root length measurement by image analysis. Plant Soil 216: 117-127.

LAMONT W.J., 1993. Plastic mulches for the production of vegetable crops. HortTechnology 3(1): 35-39.

Nevins D.J., 1995. Sugars: their origin in photosynthesis and subsequent biological interconversions. Am. J. Clin. Nutr. 61(4): 915-921.

OrŁowski M., JADCZAK D., ŻuraWiK A., 2005. The effect of covering and diameter of planted bulbils on the quantity and quality of shallot grown for bunching harvest. Zesz. Nauk. AR we Wrocławiu 515: 387-393 [in Polish with English summary].

Отto R.F., Gimenez C., Castilla N., 2000. Evapotranspiration and dry matter production of horticultural crops under cover. Acta Hort. 516: 23-30.

Polish Norm for Cucumber No. PN-85/R-75359. Rozporządzenie Ministra Rolnictwa i Gospodarki Żywnościowej z dn. 27.06.1997 w sprawie obowiązku stosowania Polskich Norm Dz.U.1997.83.535.

Rekowska E., 2011. The effect of soil and plants covering with the polypropylene non-woven on the quantity and quality of yield of stem lettuce (Lactuca sativa L. var. Augustana irish). Acta Sci. Pol., Hortorum Cultus 10(1): 3-11.

SiweK P., 2002. Modification of environmental conditions by mulching and direct plant covering in the culture of cucumber and stalk celery. Zesz. Nauk. AR w Krakowie, ser. Rozprawy 279.

Siwek P., Libik A., Gryza I., Niekraszewicz A., CiechańskA D., 2009. Physico-mechanical properties and utility of melt - blown biodegradable nonwovens. Mat. Conf. XVIII Int. Congr. CIPA and XI Int. Congr. CIDAPA, Almeria.

Siwek P., Libik A., Zawiska I., 2012. The effect of biodegradable nonwovens in butterhead lettuce cultivation for early harvest. Folia Hort. 24(2): 161-166.
Sonneveld C., Kreij C., 1999. Response of cucumber (Cucumis sativus L.) to an unequal distribution of salts in the root environment. Plant Soil 209: 47-56.

Wolfe Dw., Albright L.D., Wyland J., 1989. Modelling row covers effects on microclimate and yield: Growth response of tomato and cucumber. J. Amer. Soc. Hort. Sci. 114: 562-568.

Yemm E.W., Willis A.J., 1954. The estimation of carbohydrates in plant extracts by anthrone. Biochem. J. 58: 508-514.

\section{WPŁYW BIODEGRADOWALNYCH OSŁON BEZPOŚREDNICH NA ROZWÓJ SYSTEMU KORZENIOWEGO, WIELKOŚĆ I JAKOŚĆ PLONU OGÓRKA}

Streszczenie: Przedstawiono wyniki trzyletnich (2009-2011) badań z wykorzystaniem do bezpośredniego osłaniania roślin ogórka dwóch włóknin biodegradowalnych (IBWCH $75 \mathrm{~g} \mathrm{~m}^{-2}$ i PLA $54 \mathrm{~g}$ $\mathrm{m}^{-2}$ ). Nasiona ogórka partenokarpicznego 'Mirabelle' $\mathrm{F}_{1}$ wysiano bezpośrednio do gruntu na początku maja/czerwca i jednocześnie przykryto włókninami biodegradowalnymi. Jako kontrolę przyjęto rośliny nieosłonięte. Osłony utrzymywano do momentu pojawienia się pierwszych kwiatów. Owoce ogórka zbierano co 3 dni przez okres 5-6 tygodni. W laboratorium w owocach oznaczano zawartość suchej masy, cukrów rozpuszczalnych oraz jonów azotanowych. Po wykonaniu ostatniego zbioru owoców wykopano całe roślin ogórka z gleby - wraz z systemem korzeniowym, który następnie został poddany analizom pod względem: masy, całkowitej powierzchni, całkowitej długości oraz przeciętnej średnicy rozgałęzienia. Doświadczenia wykazały, że zastosowanie osłon (niezależnie od rodzaju polimeru, z którego zostały wykonane) spowodowało wzrost wielkości plonu handlowego owoców ogórka w 2009 i 2010 roku, nie wykazano takiego w pływu w ostatnim roku doświadczeń (2011). W 2011 roku owoce ogórka zebrane z obiektów osłoniętych wykazały większą zawartość cukrów rozpuszczalnych, suchej masy $\mathrm{w}$ porównaniu $\mathrm{z}$ kontrolą. Zastosowanie osłon nie wpłynęło na oceniane parametry rozwoju systemu korzeniowego.

Received March 4, 2014; accepted April 19, 2014 